Rien n'est plus dangereux que les intermédiaires. Indiens, Arabes, métis, indigènes européenisés forment une barrière qui isole la race blanche et la race noire et exercent une influence regrettable sur les esprits des indigènes.

\title{
PROBLEMS OF SOCIAL ORGANIZATION IN AFRICA
}

\section{By Bruno GutManN}

\section{(See p. 429)}

IN East Africa nowadays a native of the plains on meeting a member of the old hill-tribes will say, 'Who are you?', and if he answers: 'I am a Christian', will invite him to come in and rest. The form of the answer is significant, the person questioned not giving his own name or that of his tribe or district, but making himself known according to the religious, universal, point of view. The African realizes that it is through religion that the further development of his personality and of a community-life extending beyond the tribal area will best be effected. It is more especially the broken tribes in the new settlements of the plains who so ardently long for organic forms once more, and who feel they may attain their desire through Christianity.

Such an attitude is not understood by the European, who regards the Native first and foremost as African, and only secondarily as Christian. According to his views, community-life should be modelled on the nation, the ideal form being the constitutional state. He is convinced that the Natives ought to express their community-sense nationally, as Africans, and he does not perceive how utterly overwhelming the idea of regarding himself as belonging to a continent would be to a Native-though he would set this same idea as too vast for himself. The fact that the Natives have nowhere advanced beyond tribal organizations has been regarded as showing a lack of individuation power, and is held to justify the attempt to use continental citizenship as the structural basis for community development in Africa. But we ought rather to regard the persistence of organic ties among these peoples as revealing a peculiarly strong individuality to the folk-soul, and to allow ourselves to be guided by this in helping them to develop their social constitution.

In the native world, still organic in its structure, the advent of the European acts like poison. The white man teaches the Native to regard outward things as of chief importance, and to consider body and soul as instruments in the path of progress and industry. The Native, on his part, regarding the European as a being of superior race, desires to learn his ways; his admiration turning to hatred when he finds he cannot change his own skin and nature. His deliverance comes when he recognizes that the 
European is not better than himself, but different, and that Christianity is the only binding force between them.

The word used for 'civilization' in East Africa is ustarabu, which means to assume the religion and customs of the Arabs, i.e. to model oneself on Arabic forms in speech, dress, customs, and questions of law. Ustarabu therefore means the extinction of folk-individuality, but it does not destroy personal esteem. For the arabized man became a full member of that nation, entering into eating and blood-connexions with them, and felt his manhood exalted by the influence of this wider human relation. The use of this term to express 'civilization' can only suggest to the Native the idea of the adoption of the religion and customs of Europeans, not as something apart in themselves, but in order that he might be at one with them; whereas to the European 'civilization' means material progress, and the systematic building up of each people into a state or super-state community.

Thus danger is evoked at every encounter. The Native absolves himself from all his original ties and the duties connected with them, not because he regards them as unnecessary in a new feeling for purely material things, but because he seeks nobler ties in Europeanism. In the meantime, the European, already aware of the terrible isolation produced by civilization, has begun to protect the social life of the Native. But he has not yet realized that he must choose definitely between the old spiritual social standards and the world of material standards; compromise is no longer possible.

The fundamental principles to be borne in mind in endeavouring to bring about a prosperous conjunction of the black and white races in Africa may be formulated as follows: $r$. That the formation of personal character and conscience is and remains connected with the existence of the original social forms, based on kinship, bonds with neighbours and coevals, and the orders (Ordnungen) obtaining in these. 2. That the scope of these orders must not be questioned, and their authority must not be limited. 3. That the responsible persons of these groups should be used primarily as pillars of selfgovernment, and that it is through them that the co-administration of the large new allied body, arising out of the cultural and economic conjunction of black and white, should be directed. 4. That the organizations of school and church, the industrial associations and law corporations to be established in connexion with this larger alliance, must regard the individual as a corporate member, and must arrange the organization so that he is given opportunities for the exercise of responsibility and assistance in control.

Half measures will not suffice. We must not merely hand over the administration to the chiefs and require from them concurrence with the elders, it is the combined representation of the people that is important. The office of chief is becoming too individual under European influence. A chief's natural council is composed of the heads of the family-groups (Sippen- 
bäupter) of his area. Among the Wachagga there were three such familygroups, forming a group in which exchange of sisters was practised-i.e. a group having marriage relations-and it was possible to form a not unwieldy council of family heads from the representatives of this large three-family group in regular alternation. The provisional measure for the installation of a leader in the council of elders would, of course, be the assembling of the family-group (Sippe) itself. Appointments made in this manner would restore soundness to the constitution in every direction and it would have a binding effect on the individual if in every case he was treated before this council of elders as a member of a family-group, and classed together with the nearest related members of his kin for the course of the proceedings.

The breaking-up of the age-class system and the growing disrespect for the elders are the gravest evils. The influence of the European not only withdraws the young from the control of their elders, but also fills them with the dangerous illusion that they will have a happier future if they look to him; whereas they are suffering one loss after another. Their vocabulary is becoming steadily poorer because they despise the teachings of the old people. Their tastes and manner of life, based on clumsy imitation of the European, are dissipated. Emancipated from the counsel of their elders, they contract marriages lightly, and in this way also hasten the degeneration of the race.

The only remedy lies in the recognition of the age-class system as a power of first tank in the constitutional life of the Native. In this teachers, employers, and missionaries should all work together. Every educational institution could help by the recognition of the divisions and sections in the age-classes, and by restoring the guiding powers of the older classes. Plantation labourers might be associated in fellowships with extensive powers of self-government respecting their own concerns, with the support of the elders. A comparison may be made with the old artel system of Russia, in which skilled workmen offered and performed services in associated bodies, a fact which had the greatest educative influence on them and also procured them higher wages.

The acquisitive sense awakened by European-American civilization has made even the soil an element of danger to the Native. Among the Dschaggas man and wife often plant their fields separately, so that neither may control the crops of the other. So much of the farm produce is sold that the children suffer from under-nourishment and do not reach the standard of their race. Then, too, the cultivation of plants like cotton and coffee for trading purposes prevents land-settlement on sound lines. These plantations are widening the gulf between rich and poor to an extent hitherto unknown; and, what is even worse, they make the Natives dependent on the world-market, thus endangering their existence economically.

The artels of the Russian economic system show that capitalism does not presuppose or give rise to an amorphous mass of people, and that these 
ancient group-forms have astonishing powers of adaptability, which, influenced and directed by sociologists, might be developed into quite different forms also satisfactory to the working-class. From Professor Lederer's description of the state of transition in the economic system of Japan, it is clear that capitalism there would be able to create a sociologically new class of workers-organically connected with the various enterprises-if the 'group-feeling' on both sides were developed satisfactorily. With these examples of the possibility of maintaining life in natural groups even in connexion with capitalism and great trading interests, we might reasonably fight for the preservation of African group-forms even in gold-fields and diamondmines. How much more ought we to strive for this, seeing that the bulk of the African world has remained agricultural.

Sombart, in his latest book, says that the significance of capitalism and modern methods of industrialism and commercialism, as regards worldeconomics, is considerably overestimated. The agrarian system of economics is still by far the most important, comprising two-thirds of the whole of mankind. Sombart also believes he can see indications of slowing-down of capitalist energy - signs even of the beginning of a standstill.

The individual white man should realize his responsibility as a member of the leading race, whose manner of life will be imitated. Too little heed is paid to the fact that the frequent lack of physical control and spiritual selfdiscipline is weakening the morals of the Native.

But it is in our conscious efforts that we are most dangerous to the African -above all in connexion with the schools. A school ought to reflect the organic connexions of native society, and enter into reciprocal relations with the responsible leaders of the organic folk-group. We are fast making this impossible by raising the salaries of teachers higher and higher through State aid-thus removing them from the ordinary life of the rest of the people, and depriving them of structural connexion with them.

This is due to the desire to make the teacher the agent of our constructive ideas through his work in the school, and it is through such educational agents that we lose the personal contact with the Native that alone will achieve the happy conjunction of both races. The only African school deserving of the name would be one in which the ideal would be to try to instruct the pupils in the structure of the folk-group down to its foundation and teach them to appreciate its value, recognizing its importance in two ways: by allowing the structural connexions of the pupils themselves to continue to exist in the school, and basing the activity of the school-world on these; and by gathering the community, represented by the group-leaders, round the school as a co-directing council, thus bringing the school more and more into organic connexion with the people as a whole. This should be done as regards both elementary and secondary schools. 
Nothing is more fatal than having recourse to go-betweens. Such agentsIndians, Arabs, half-castes, europeanized Natives-form an isolating barrier between black and white races, and exercise a disturbing influence on the minds of the Natives.

\section{LA DANSE \\ Par E. E. Evans-Pritchard}

(Voir p. 446)

EN général les travaux d'ethnologie n'accordent pas à la danse la place et l'importance qu'elle mérite, on voit trop souvent en elle une forme indépendante d'activité alors qu'elle a une fonction physiologique aussi bien que psychologique d'une portée sociale.

Le but du présent travail est d'analyser une danse pratiquée par les Azandé, peuplade habitant sur les confins du Congo Belge, de l'Oubagni-Chari français et du Soudan anglo-égyptien. Il ne sera parlé ici que du gbere buda (danse de la bière) et des éléments qui la composent: musique, chant et mouvement, sans l'ensemble desquels la danse serait inconcevable.

Musique. Les instruments de musique sont des résonateurs en bois et des tambours également en bois et recouverts de peau à une extrémité. Les premiers, de très grande taille, sont taillés dans des troncs d'arbre, ont la forme d'un buffle, ils sont creux avec une fente supérieure, les deux parois d'épaisseur différente donnent des sons variables, obtenus par le choc de baguettes, dont l'extrémité est recouverte de cuir. Les tambours, hauts de trois ou quatre pieds, sont plus larges en bas qu'en haut, on les bat à la main.

Chant. Le chant accompagne toujours la musique de ces instruments. L'auteur n'a pu noter de mélodies au moyen du phonographe, ces mélodies suivent la mode, elles s'oublient aisément. Tous ces chants ont une signification, mais, si le compositeur comprend celle-ci et sait la commenter, les chanteurs souvent n'en saisissent pas le sens; la mélodie ayant seule de l'importance à leurs yeux, ils apportent de nombreux changements aux paroles. D'autre part le chant est toujours accompagné de mouvements des muscles qui font en quelque sorte partie de la mélodie aussi bien que les paroles. Dans la 'danse de la bière' ces chants ont une structure spéciale, étant composés d'un vers chanté par le soliste (undu) et d'un chœur (bangwa). Les Azandé distinguent en dehors de cela dans leurs chants le sima, qui semble être dans certains cas la reprise en chcur du solo.

MOUVEMENTS MUSCULAIRES. L'Africain danse non seulement avec les pieds mais avec tout le corps, et bien que chaque individu ne fasse pas toujours les mêmes mouvements que les autres, tous accomplissent ces mouvements suivant un certain rythme. Il y a bien des pas imposés, mais ceux-ci peuvent être modifiés, comme la mélodie, par la mode. 